\title{
Sustainability of Mahogany Production in Plantations: Does Resource Availability Influence Susceptibility of Young Mahogany Plantation Stands to Hypsipyla robusta Infestation?
}

\author{
C. B. Darko, ${ }^{1}$ E. Opuni-Frimpong $\mathbb{D}^{, 2,3,4}$ S. A. Owusu, ${ }^{3}$ B. Kyere, ${ }^{1}$ and A. J. Storer ${ }^{4}$ \\ ${ }^{1}$ Kwame Nkrumah University of Science and Technology, Kumasi, Ghana \\ ${ }^{2}$ University of Energy and Natural Resources, P.O. Box 214, Sunyani, Ghana \\ ${ }^{3}$ CSIR- Forestry Research Institute of Ghana, University, P.O. Box 63, Kumasi, Ghana \\ ${ }^{4}$ College of Forest Resources and Environmental Science, Michigan Technological University, 1400 Townsend Drive, Houghton, \\ MI 49931, USA \\ Correspondence should be addressed to E. Opuni-Frimpong; eopunifr@gmail.com
}

Received 27 January 2021; Accepted 16 December 2021; Published 19 January 2022

Academic Editor: Monika Marković

Copyright (c) 2022 C. B. Darko et al. This is an open access article distributed under the Creative Commons Attribution License, which permits unrestricted use, distribution, and reproduction in any medium, provided the original work is properly cited.

\begin{abstract}
Hypsipyla robusta Moore (Lepidoptera: Pyralidae), like many other moth species, shows selectivity when choosing host plants for its eggs. Four Meliaceae species (Khaya grandifoliola, K. ivorensis, Swietenia macrophyla, and Entandrophragma cylindricum) were established in a moist semideciduous forest in Ghana to study this selectivity at 12 and 21 months after planting. The analysis of variance (ANOVA) at a $P$-value of 0.05 was used to test the significance of differences in infestation by $H$. robusta between the species. H. robusta attacks were recorded by month 12 after planting in the field, and only Khaya spp. was attacked, with attacks evident on $15.5 \%$ of $K$ grandifoliola and $6.6 \%$ K. ivorensis. Saplings in blocks closer to an older H. robusta infested K. grandifoliola stand had more infestation compared to saplings further away. The mean percentage of $K$. grandifoliola attacked was $38.9 \%, 38.9 \%$, $13.3 \%$, and $7.4 \%$ in 4 different plots located increasingly further away from the older infested plantation. A similar trend was found in $K$. ivorensis with $28.4 \%, 7.1 \%, 0.0 \%$, and $0.0 \%$ in the plots located increasingly further away from the infested stand. These results indicate a higher number of shoot borer attacks at the edge of the plantation and in proximity to other infested plantations. After 21 months, the fastest-growing species and the fastest-growing individuals within the species were the most infested. K. grandifoliola recorded the fastest growth and most attacks followed by K. ivorensis and S. macrophylla. E. cylindricum recorded the least growth and no $H$. robusta infestation. After 21 months, the mean percentages of trees attacked were 59.1\%, 23.7\%, 5.6\%, and $0.0 \%$ for K. grandifoliola, K. ivorensis, S. macrophylla, and E. cylindricum, respectively. Within species, the fastest-growing saplings experienced the most attacks. A positive correlation was observed between the plant size and $H$. robusta attacks $\left(R^{2}=0.76\right)$. Attacks resulted in the death of the apical shoot and the proliferation of multiple shoots in only the Khaya spp., with $K$. ivorensis recording a lower number of shoots than $K$. grandifoliola. These proliferated shoots were also attacked, and a positive correlation was observed between the number of proliferated shoots and $H$. robusta attacks $\left(R^{2}=0.84\right)$. These findings will assist plantation developers, forest managers, and investors in mahogany plantations to devise integrated pest management strategies to reduce the impact of Hypsipyla attacks on their plantations.
\end{abstract}

\section{Introduction}

The Hypsipyla (Lepidoptera: Pyralidae) shoot borers cause significant damage to high-value timber species of the Meliaceae and Verbenaceae families. The two most important Hypsipyla species are Hypsipyla grandella, which occurs in the Neotropics, and Hypsipyla robusta, which occurs throughout tropical Africa, Asia, and the Pacific region, including Australia [1]. H. grandella attacks species from the genera Cedrela, Swietenia, and Toona in the Neotopics. H. robusta, on the other hand, is reported to attack Carapa procera, Khaya anthotheca, K. ivorensis, K. grandifoliola, K. senegalensis, Entandrophragma angolense, E candolei, E. cylindricum, E. utile (all African 
mahoganies), and Lovoa trichiliodes; native to tropical Africa and Chukrasia tabularis, Toona spp. (T. australis, T. ciliata); native to Asia and Australia, respectively [2-5].

The main damage caused by Hypsipyla spp. is inflicted by the larvae, which destroy the principal terminal shoot by boring into the tips and tunneling in the stems of young saplings [4-7]. The larvae of Hypsipyla feed on the soft tissue inside the stem. This results in heavy sap exudation, which can lead to killing the main stem [4]. The new shoots that grow in response to shoot borer attacks are also attacked repeatedly by the larvae, and they result in the development of multiple side branches and poorly formed trees, which are undesirable for timber production [6, 8-10]. Attacks by Hypsipyla are usually more severe on the stands growing in full sun, and hence, the biggest effects are observed in young plantations, and especially those in monocultures [11-13]. Saplings growing under shade suffer far less damage [12] but at the expense of vigorous growth associated with mahoganies. The control of Hypsipyla shoot borers has proven unsuccessful despite significant research and management efforts, which have employed biological, chemical, and silvicultural methods [14-16].

The feeding habits of some insects exhibit a pattern where the host plants located at the boundary of a forest plantation of the same family are attacked more than those in the interior [17]. Darko [18] predicted that the closeness of $H$. robusta insect colonies to a host plant stand might influence the susceptibility of the stand to attacks. However, information on the pattern of attacks in relation to the edge effect is very limited. In earlier studies of species in the Khaya and Entandrophragma genera, $H$. robusta showed a higher affinity for the Khaya species $[12,19]$.

Female shoot borers are attracted to fast-growing individuals when searching for oviposition sites as they may have more growing shoots available [20], some of which may be succulent and thick enough to ensure the survival and better performance for the larvae. Hypsipyla robusta is reported to exhibit this selectivity even when choosing among different individuals of the same species as the host [21]. It could explain why faster-growing mahoganies, especially those in the open field plantations, usually have higher infestation rates than those in the shade or those that are slower-growing species $[12,22]$.

We examined the pattern of $H$. robusta attacks on four Meliaceae species (Khaya grandifoliola, Khaya ivorensis, Swietenia macrophylla, and Entandrophragma cylindricum) in relation to their size, availability of shoots or resources, and the closeness of stands to an $H$. robusta infested $K$. grandifoliola stand in the moist semideciduous forest of Ghana. It was our expectation that the findings could be used to develop strategies for managing Hypsipyla in young mahogany plantations.

\section{Materials and Methods}

2.1. Species, Study Site, and Establishment of Plots. This study was located in the moist semideciduous forest type [23] of Ghana's Upper Guinean tropical forest. This forest type is favorable for the growth of all native West African mahogany species $[23,24]$. The annual precipitation ranges between 1200 and $1750 \mathrm{~mm}$ per annum, with a dry season from December to March with a rainfall of less than $100 \mathrm{~mm}$ per month. All experiments were established at the Forestry Research Institute of Ghana (FORIG) Mesewam nursery and research center near Kumasi.

The four study species are K. grandifoliola, K. ivorensis, E. cylindricum, and S. macrophylla. Twelve seedlings of each of the four species (treatments) were planted per plot at a spacing of $2 \mathrm{~m} \times 2 \mathrm{~m}$. Each species (treatment) was replicated four times in a randomized block design. All the plots used were weeded regularly to reduce competition with weeds and also for easy access during data collection. No other silvicultural manipulations were carried out on any of the plots during the period of monitoring.

2.2. Data Collection. For each of the four species (K. grandifoliola, K. ivorensis, E. cylindricum, and S. macrophylla), data were collected 12 and 21 months after planting. The total height was measured from the stem base of each plant to the tip of the leading shoot, and the height of the clear trunk (height to the first fork) was measured from the base of the plant to the base of the first branch [25]. The diameter of each plant was measured $10 \mathrm{~cm}$ above the ground [26].

We assessed $H$. robusta attacks by visually inspecting each plant for the presence of frass and dieback with or without the development of new or multiple shoots. The total number of shoots growing per plant was counted along with the number of shoots attacked per plant $[12,27]$.

2.3. Data Analyses. Data collected for each species were grouped into $H$. robusta-attacked and -nonattacked saplings, and the relationships established were as follows:

(a) Plant size (mean height, diameter, and height at the first fork) of $H$. robusta-attacked and -nonattacked saplings for each of the four species

(b) Mean shoots proliferated per plant and mean shoots attacked per plant

(c) The influence of the proximity of plots to an older $H$. robusta infested $K$. grandifoliola plot

The means of the data were calculated, and overall differences among the species (treatments) were tested using the analysis of variance (ANOVA) at a $P$-value of 0.05 , followed by Tukey's test (Post hoc test) to compare treatment pairs. Analyses were conducted using Statistixl [28] and Graphpad Prism 5 software [29] (http://www.statistixl.com; http://www.graphpad.com). The relationships between variances and means were compared, and where necessary, the data were transformed.

\section{Results}

3.1. Relationship between Saplings/Plant Size and Incidence of Attack. The data collected on the 4 species and analyzed twelve months after planting in the field showed significant 
differences $(P=0.041)$ in $H$. robusta attack among the species, as only the Khaya species had recorded attacks with a mean percentage of $15.5 \%$ of $K$. grandifoliola and $6.6 \%$ of K. ivorensis trees attacked (Table 1). The mean height and diameter of the attacked saplings were greater than those that were not attacked within each species (Figures 1(a) and 1(b)). This trend was again evident 21 months after planting in the field. However, the mean height of the attacked trees was $1.46 \mathrm{~m}, 1.25 \mathrm{~m}$, and $1.79 \mathrm{~m}$ for $K$. grandifoliola, K. ivorensis, and S. macrophylla, respectively, and the mean heights of the nonattacked individuals were $1.11 \mathrm{~m}, 0.85 \mathrm{~m}$, and $1.05 \mathrm{~m}$ for $K$. grandifoliola, $K$. ivorensis, and S. macrophylla, respectively (Figures 2(a) and 2(b)). At the end of the $21^{\text {st }}$ month, $S$. macrophylla had also been attacked by $H$. robusta (Table 1), and the mean percentages of trees attacked were $59.1 \%, 23.7 \%, 5.6 \%$, and $0.0 \%$ for K. grandifoliola, K. ivorensis, S. macrophylla, and E. cylindricum, respectively, and they varied significantly $(P=0.000)$. The same trend was observed, whereby the mean height and corresponding diameters of the attacked saplings recorded higher values than those of the nonattacked saplings (Figures 2(a) and 2(b)).

3.2. Height of Clear Trunk and the Relationship between Average Shoots Developed and Shoot Attacked. The number of shoots sprouted on the attacked saplings of each species was generally higher than the number on nonattacked saplings. It was also significantly higher for all the species at 12 and 21 months with the exception of $K$. grandifoliola at 12 months (Figure 3 ). In the $12^{\text {th }}$ month, when the attack was first observed in K. ivorensis and K. grandifoliola, their mean shoots per sapling was 1.1 and 1.26, respectively, while the other two species (S. macrophylla and E. cylindricum) recorded an average of 1.0 leading shoot per plant (Table 2). Twenty one months after planting in the field, K. grandifoliola, K. ivorensis, and $S$ macrophylla had $4.3,3.0$, and 4.0 mean sprouted shoots in response to Hypdsipyla attacks, while the nonattacked trees had 2.1, 1.5, and 1.2 mean shoots for K. grandifoliola, K. ivorensis, and $S$ macrophylla, respectively. The percentage of shoots that were attacked varied among the species. Entandrophragma cylindricum recorded a $0 \%$ shoot attack for the entire data collection period, while S. macrophylla recorded only $2.8 \%$ shoot attack in the $21^{\text {st }}$ month. Khaya ivorensis recorded $27.1 \%$ and $44.0 \%$, while $K$. grandifoliola also recorded $47.0 \%$ and $44.9 \%$ shoots attack for the $12^{\text {th }}$ and $21^{\text {st }}$ months, respectively (Table 2 ).

With reference to the attacked and nonattacked trees, the height of the clear trunk was greater for the attacked trees. For each species on each measurement date, the difference in the height of the clear trunk between the attacked and nonattacked trees was significant $(P<0.05)$, with the exception of K. grandifoliola at month 12 (Figure 4). The mean height of the clear trunk recorded was $0.88 \mathrm{~m}, 0.88 \mathrm{~m}$, and $0.99 \mathrm{~m}$ for the attacked K. grandifoliola, K. ivorensis, and $S$ macrophylla, respectively, compared with $0.65 \mathrm{~m}, 0.66 \mathrm{~m}$, and $0.41 \mathrm{~m}$ for the nonattacked $K$. grandifoliola, K. ivorensis, and $S$ macrophylla, respectively.
The attacks of the leading shoots as observed in the $12^{\text {th }}$ month led to the proliferation of multiple shoots, which were also subsequently attacked. The regression equation between the shoot attacked on the total shoots developed by each sapling showed a positive relationship for $K$. ivorensis $\left(R^{2}=0.76\right)$ and K. grandifoliola $\left(R^{2}=0.84\right)$ (Figures 5 and 6$)$. The relation was developed for only $K$. ivorensis and K. grandifoliola since they recorded significant attack levels and subsequently developed multiple shoots.

\subsection{Proximity to Infested Plots as a Factor for Sapling} Infestation. Twelve months after planting, it was observed that the saplings in the blocks closer to a four-year-old K. grandifoliola stand recorded higher levels of attack. Block 1 was the closest to the older K. grandifoliola stand, followed by blocks 2, 3, and 4 (Figure 7 ). The percentage of saplings attacked in blocks 1, 2, 3, and 4 for the Khaya species, which were the only attacked species in month 12 , was the highest in block 1, and it decreased from blocks 2, 3, and 4, respectively (Table 3 ). None of the saplings of E. cylindricum and S. macrophylla arranged in the blocks of the Meliaceae species trial was attacked 12 months after planting. Hence, a proximity effect was not evident.

\section{Discussion}

4.1. Relationship between Sapling/Plant Size and Incidence of Attack. Data collected at the end of 12 and 21 months were regrouped into the attacked and nonattacked saplings for each of the four species. The three species $K$. ivorensis, K. grandifoliola, and S. macrophylla had some of their saplings attacked in this study and showed similar trends. The attacked saplings were relatively taller and bigger than the nonattacked ones, which were shorter and smaller and corroborated the vigor hypothesis [30]. Cunningham and Floyd [31] and Mo et al. [20] also reported a similar trend of positive correlation between Hypsipyla attacks and plant size in Toona species. Khaya grandifoliola was the fastest and the tallest growing among the four Meliaceae species, which could have contributed to its saplings being more attractive to and preferred by $H$. robusta, thereby resulting in its saplings experiencing more attacks than the other species [22, 31, 32].

Female insects are attracted to fast-growing trees because they have more growing shoots available [20], some of which may be thick. Hypsipyla may prefer to oviposit on the thick succulent shoots $[22,33]$, probably as a means of ensuring the survival of its progeny [34]. In the field and laboratory experiments, insects tend to be attracted to the shoots and leaves of relatively fast-growing trees than those of the slowgrowing ones $[22,34,35]$. It may explain why saplings that were attacked were relatively tall and big.

Although not examined in this study, the attractiveness of a tree to the insects is usually based on the nutritional value of the plant [22], which, according to Heisswolf et al. [34], is very high in larger (fast-growing) trees than the smaller ones. It may be attributed to changes and/or increases in the production of certain chemicals in these fastergrowing species in the open, which may affect the signal that 
Taвle 1: Percentage of K. grandifoliola, S. macrophylla, K. ivorensis, and E. cylindricum saplings attacked in the species trial after 12 and 21 months in the moist semideciduous forest.

\begin{tabular}{lcc}
\hline Treatment & & Percentage of saplings attacked (\%) \\
\hline K. ivorensis & 12 months & 21 months \\
K. grandifoliola & $6.607^{\mathrm{a}} \pm 5.482$ & $23.686^{\mathrm{a}} \pm 6.193$ \\
E. cylindricum & $15.483^{\mathrm{a}} \pm 5.194$ & $59.060^{\mathrm{b}} \pm 11.954$ \\
S. macrophylla & $0.000^{\mathrm{a}} \pm 0.000$ & $0.000^{\mathrm{a}} \pm 0.000$ \\
$P$ values & $0.000^{\mathrm{a}} \pm 0.000$ & $5.556^{\mathrm{a}} \pm 5.556$ \\
\hline
\end{tabular}

Values are percentages, and \pm are standard errors. Percentages in the same column with the same letter are not statistically different at P value of 0.05 . Differences between means were compared using Tukey's test (Post Hoc tests).

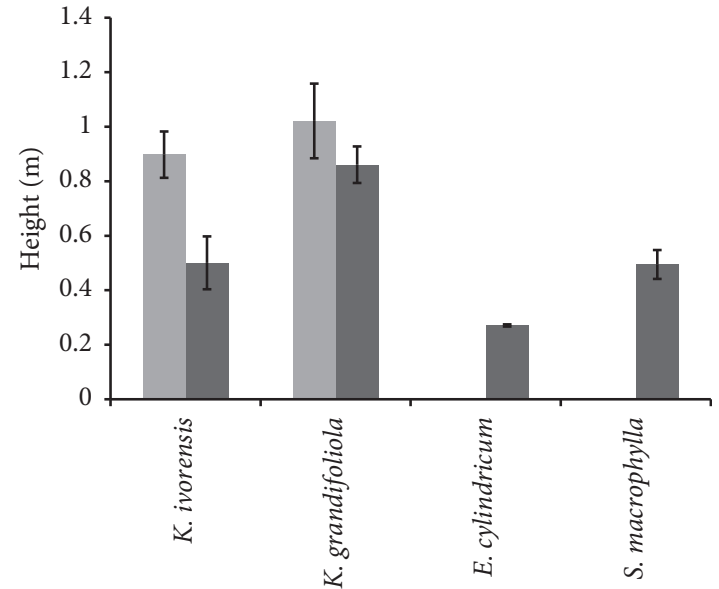

Species

- Attacked saplings

- Non attacked saplings

(a)

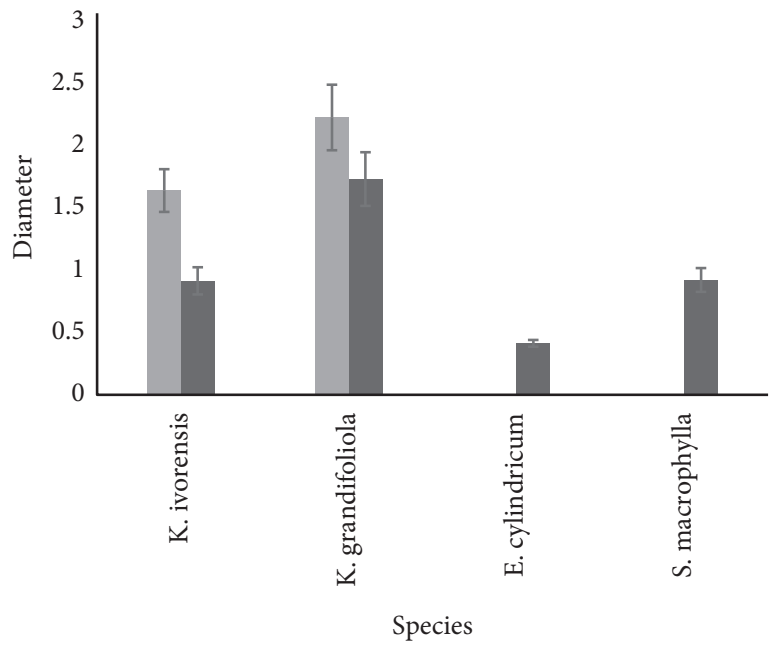

- Attacked saplings

- Non attacked saplings

(b)

FIGURE 1: Mean height (a) and diameter (b) of the attacked and nonattacked saplings of the four Meliaceae species 12 months after planting.

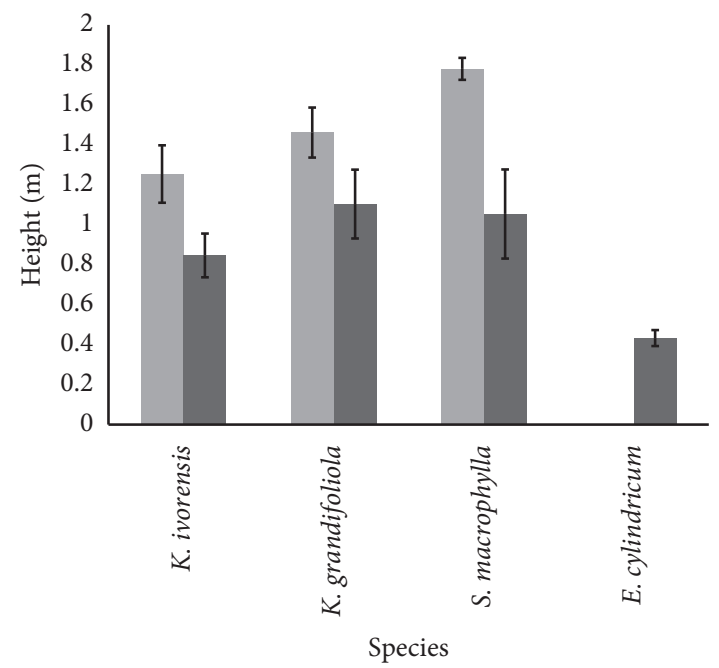

- Attacked saplings

- Non attacked saplings

(a)

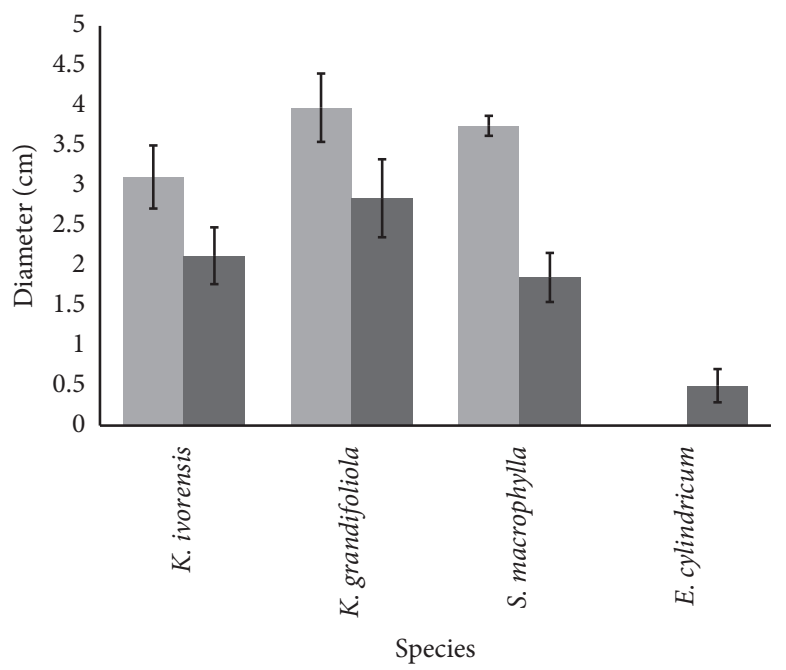

- Attacked saplings

- Non attacked saplings

(b)

FIGURE 2: Mean height (a) and diameter (b) of the attacked and nonattacked saplings of the four Meliaceae species 21 months after planting. 


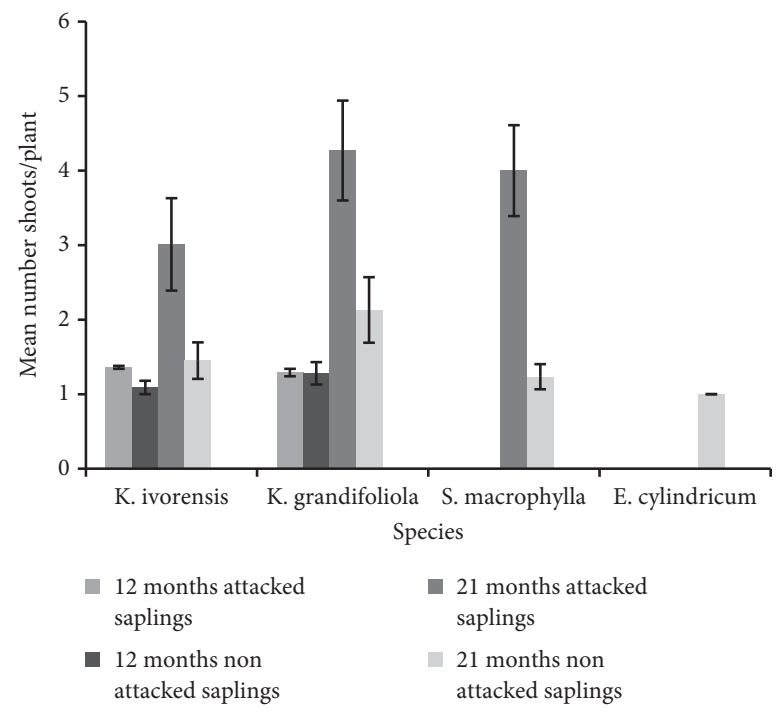

FIGURE 3: Mean number of shoots on the attacked and nonattacked saplings of the four Meliaceae species 12 and 21 months after planting in the moist semideciduous forest.

TABLE 2: Mean shoots and percentage shoots attacked for K. grandifoliola, S. macrophylla, K. ivorensis, and E. cylindricum in the species trial 12 and 21 months after planting in the moist semideciduous forest.

\begin{tabular}{lcccc}
\hline Treatment & \multicolumn{2}{c}{ Mean shoots } & \multicolumn{2}{c}{ Percentage of shoots attacked (\%) } \\
& 12 months & 21 months & 12 months & 21 months \\
\hline K. ivorensis & $1.100^{\mathrm{a}} \pm 0.019$ & $2.056^{\mathrm{a}} \pm 0.352$ & $27.120^{\mathrm{a}} \pm 19.581$ & $43.955^{\mathrm{a}} \pm 10.432$ \\
K. grandifoliola & $1.257^{\mathrm{b}} \pm 0.052$ & $3.859^{\mathrm{b}} \pm 0.342$ & $47.040^{\mathrm{a}} \pm 11.905$ & $44.898^{\mathrm{a}} \pm 8.752$ \\
E. cylindricum & $1.000^{\mathrm{a}} \pm 0.000$ & $1.000^{\mathrm{c}} \pm 0.000$ & $0.000^{\mathrm{a}} \pm 0.000$ & $0.000^{\mathrm{b}} \pm 0.000$ \\
S. macrophylla & $1.000^{\mathrm{a}} \pm 0.000$ & $1.000^{\mathrm{c}} \pm 0.000$ & $0.000^{\mathrm{a}} \pm 0.000$ & $2.750^{\mathrm{b}} \pm 2.750$ \\
$P$ values & 0.000 & 0.000 & 0.035 & 0.000 \\
\hline
\end{tabular}

Values are percentages, and \pm are standard errors. Percentages in the same column with the same letter are not statistically different at P value of 0.05 . Differences between means were compared using Tukey's test (Post Hoc tests).

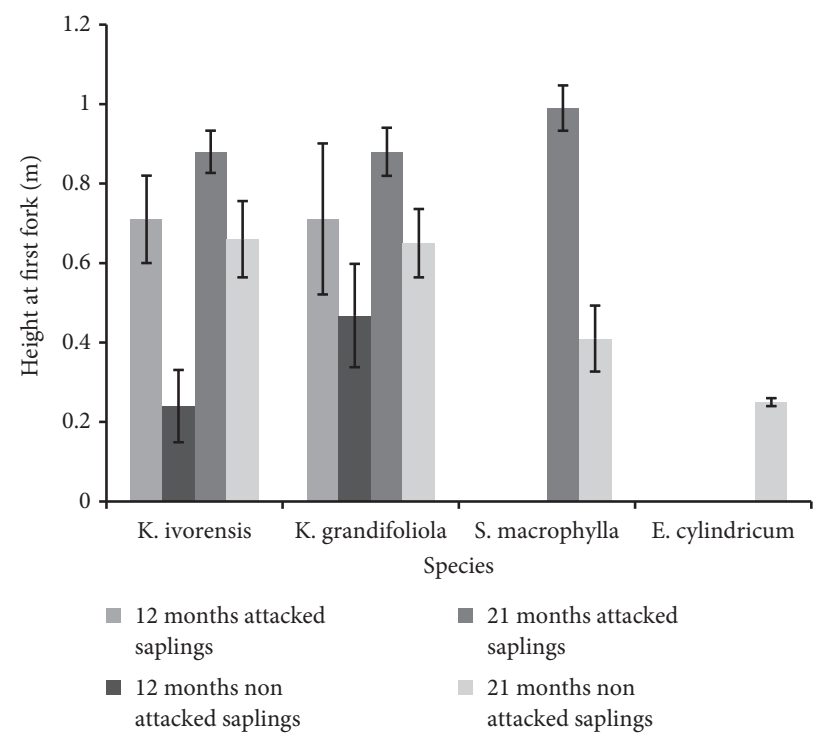

FIGURE 4: Mean height to the first fork of the attacked and nonattacked saplings of the four Meliaceae species 12 and 21 months after planting in the moist semideciduous forest.

attracts the adult lepidopterans for oviposition [22, 34]. Mahroof et al. [22] further suggested that if antifeedants indeed exist in mahoganies, then they may be inactive or absent during the early flushing of leaves since this is the period of intense attack. Slow-growing plants, on the other hand, are woodier, have poor quality resources and low nutritional value for larvae development [36], and may be fortified with antiherbivory chemicals. 


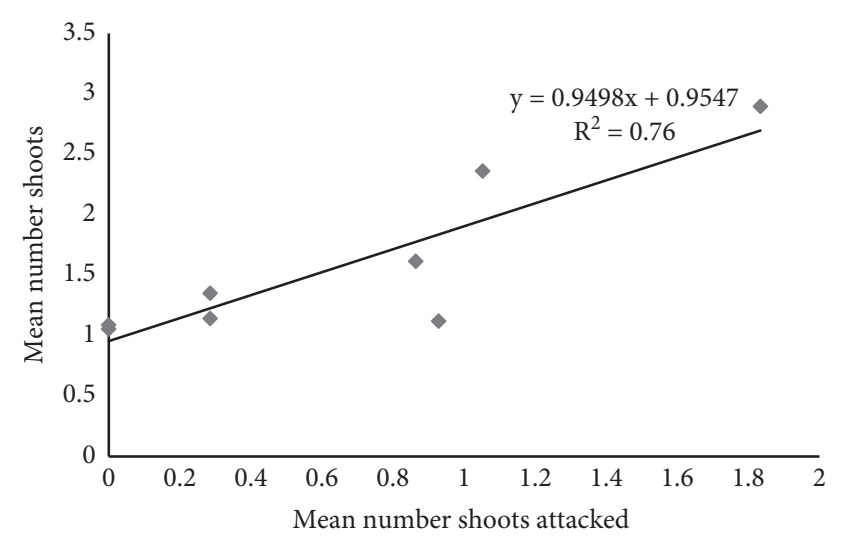

FIGURE 5: Relationship between the mean number of shoots and the mean number of shoots attacked for K. ivorensis in the species trial 21 months after planting in the moist semideciduous forest.

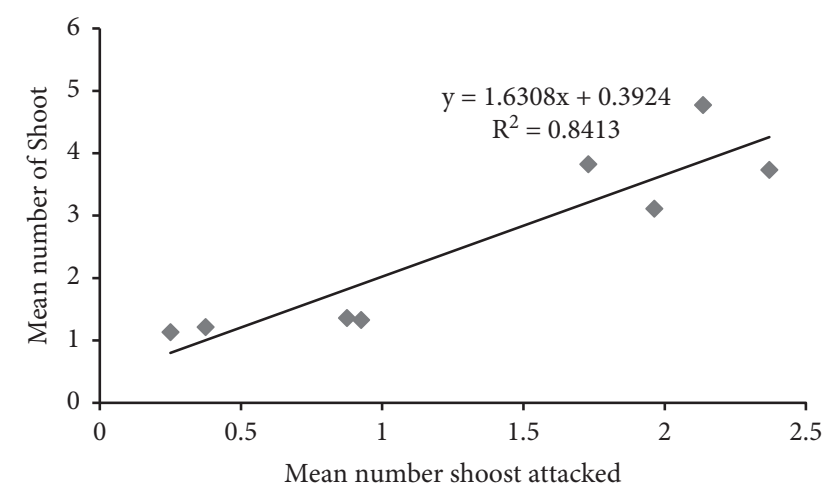

FIGURE 6: Relationship between the mean number of shoots and the mean number of shoots attacked for K. grandifoliola in the species trial 21 months after planting in the moist semideciduous forest.

4.2. Height of Clear Trunk and the Relationship between the Average Shoots Developed and Shoots Attacked. The Meliaceae often produce an average of one leading shoot per plant in the absence of Hypsipyla attacks [12]. Eight months after planting, observations indicated that none of the species was attacked, and the number of shoots per sapling was one. With the onset of attack that resulted in the death of the apical dominant shoot $[26,32]$ by the $12^{\text {th }}$ month in general, both Khaya species had the mean number of shoots sprouted to be 1.1 and 1.3 for K. ivorensis and K. grandifoliola, which increased to 2.1 and 3.9 , respectively, in the $21^{\text {st }}$ month. These sprouting shoots were considered a suitable substrate for egg deposition and the development of larvae of the Hypsipyla moth [37] and were also attacked. Hence, a positive linear relationship between the shoots attacked and the total shoots of $K$. grandifoliola and K. ivorensis was observed in the trial.

The number of shoots recorded for the attacked saplings of $K$. grandifoliola, $K$. ivorensis, and S. macrophylla at the end of the $21^{\text {st }}$ month was more than double that was recorded in the $12^{\text {th }}$ month. It suggests that as new shoots are sprouting as a result of attacks, the new shoots also get attacked, causing more shoots to develop, thereby increasing the availability of resources
[20] that may be suitable for $H$. robusta to feed on or attack. Similar results have been reported for Toona ciliata, which is also in Meliaceae [38]. Entandrophragma spp. had no attacks, and thus they generally had a single shoot that conformed to the observations made by OpuniFrimpong et al. [3]

The significantly greater height of the clear trunk recorded by the attacked saplings could be attributed to the attacked saplings showing some level of recovery after the attacks by shedding off the old branches. The increase in the mean height of the clear trunk for $K$. grandifoliola was lower than that of $K$. ivorensis from the $12^{\text {th }}$ to the $21^{\text {st }}$ month (Figure 4). It could be attributed to the high number of shoots developed after the attack and what Opuni-Frimpong et al. [12] referred to as self-pruning. Self-pruning was observed in the K. grandifoliola but was less pronounced and similar to the observations made in $K$. anthotheca [12].

Khaya ivorensis, on the other hand, developed an average of two shoots per sapling, of which only one shoot was attacked. These relatively few sprouted shoots in response to $H$. robusta attacks together with self-pruning (which was more pronounced and a major characteristic associated with K. ivorensis) could have contributed to the better recovery and higher clear trunk observed in Khaya ivorensis [12].

Some researchers have considered self-pruning as a means of showing resistance or tolerance to Hypsipyla attacks $[3,39]$. Self-pruning, together with artificial pruning, could be used as a silvicultural tool to increase the bole length of the Meliaceae to the $8-10 \mathrm{~m}$ height, which is sought for merchantable boles $[6,25]$.

4.3. Proximity to Infested Plots as a Factor for Sapling Infestation. The experimental plot used to conduct this trial lies opposite to a forest used for research purposes, with block 1 immediately opposite to it (Figure 7). Adjacent to that forest on both sides were three- and fouryear-old Khaya grandifoliola research plots, which have experienced $H$. robusta attacks. These infested plots may had been the sources of $H$. robusta, which attacked the Meliaceae species in this study. The closeness of a food source to an insect colony may determine how fast the food source is attacked by the insect. It could explain the blocking effect observed, where the blocks (1 and 2) that were closer to the old $K$. grandifoliola stands experienced higher levels of attack than those further away but on the same plot (blocks 3 and 4) in the $12^{\text {th }}$ month. The observation conforms to that made by Darko [18] when K. grandifoliola was studied in a mixed plantation and agroforestry setting in the same location. The observation also shows a positive response of initial $\mathrm{H}$. robusta attacks to the edge effect in the Meliaceae species trial [17]. E. cylindricum and S. macrophylla were not attacked even though they were arranged in the same blocks in the Meliaceae species trial, which could be attributed to the preference of $H$. robusta to Khaya species [3]. This pattern was not maintained as attack levels generally increased in the Khaya species on the $21^{\text {st }}$ month, where S. macrophylla recorded its first attack. 


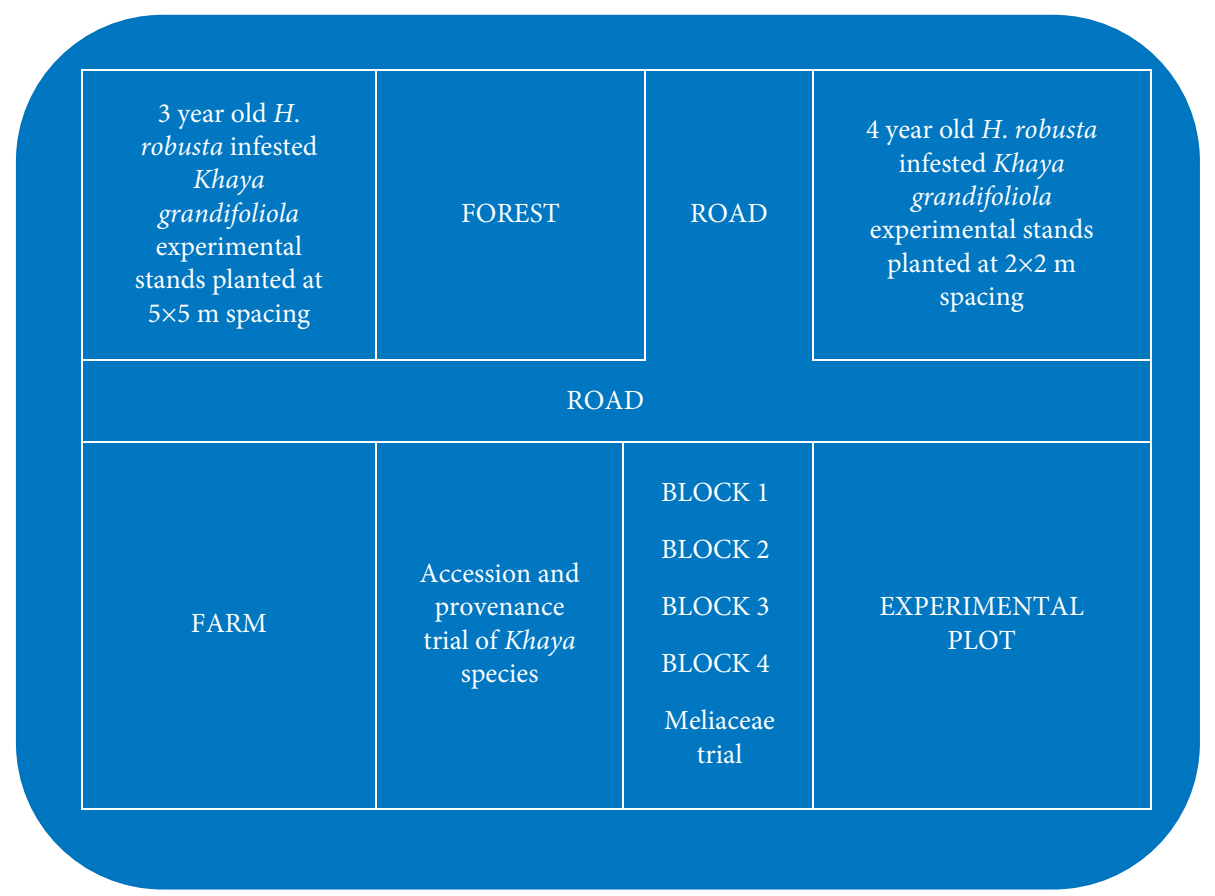

FIGURE 7: Schematic layout of the trial sites for the Meliaceae species blocks.

TABle 3: Percentage of saplings attacked by $H$. robusta in various blocks of the Meliaceae species trials in the moist semideciduous forest types in the $12^{\text {th }}$ month.

\begin{tabular}{lcccc}
\hline \multirow{2}{*}{ Accessions/species } & \multicolumn{4}{c}{ Attacked saplings (\%) } \\
& Block 1 & Block 2 & Block 3 & Block 4 \\
\hline K. ivorensis & 28.36 & 7.14 & 0.00 & 0.00 \\
K. grandifoliola & 38.88 & 38.88 & 13.33 & 7.41 \\
S. macrophylla & 0.00 & 0.00 & 0.00 & 0.00 \\
E. cylindricum & 0.00 & 0.00 & 0.00 & 0.00 \\
\hline
\end{tabular}

\section{Conclusions}

We examined the pattern of $H$. robusta attack on four Meliaceae species (Khaya grandifoliola, Khaya ivorensis, Swietenia macrophylla, and Entandrophragma cylindricum) in relation to the plant size, availability of shoots or resources, and proximity to an $H$. robusta-infested K. grandifoliola stand in the moist semideciduous forests of Ghana.

(i) The closeness of a young plantation to an already established plantation with $H$. robusta infestation may increase their vulnerability to attack, with saplings closer to the infested stands experiencing initial attacks.

(ii) Faster growing and taller saplings of each species were attacked more than the slower growing saplings.

(iii) Hypsipyla robusta infestation leads to the proliferation of multiple shoots, providing resources for further attacks and branching. The more the proliferations of the shoots, the more the shoots attacked. (iv) Saplings show recovery by the increase in the height of clear trunk over time.

Our results provide insight for further efforts aimed at developing strategies to restore mahogany species in forest landscapes in the tropics.

\section{Data Availability}

The data used to support this study will be made available upon request to the corresponding author by any one who needs it.

\section{Conflicts of Interest}

The authors declare that they have no conflicts of interest.

\section{References}

[1] FAO (Food and Agricultural Organization), Forest Pest Species Profile, FAO, Rome, Italy, 2007, http://www.fao.org/ forestry/13565-0b495b527395a3c2e411d842468d29276.pdf.

[2] FAO (Food and Agricultural Organization), Global Review of Forest Pest and Diseases. A Thematic Study Prepared in the Framework of the Global Forest Resources Assessment 2005, Food and Agriculture Organization of the United Nations, Rome, Italy, FAO Forestry Paper 156, 2009.

[3] E. Opuni-Frimpong, D. F. Karnosky, A. J. Storer, E. A. Abeney, and J. R. Cobbinah, "Relative susceptibility of four species of African mahogany to the shoot borer Hypsipyla robusta (Lepidoptera: Pyralidae) in the moist semideciduous forest of Ghana," For. Ecol. Manage.vol. 255, pp. 313-319, 2008.

[4] M. R. Wagner, J. R. Cobbinah, and P. P. Bosu, Forest Entomology in West Tropical Africa: Forest Insects of Ghana, Springer, Dordrecht, the Netherlands, Second edition, 2008. 
[5] N. M. Chi, D. N. Quang, B. Hien et al., "Management of Hypsipyla robusta moore (Pyralidae) damage in Chukrasia tabularis A. Juss (Meliaceae)," International Journal of Tropical Insect Science, vol. 41, no. 4, 2021.

[6] P. Grijpma, Contributions to an integrated control programme of Hypsipyla grandella (zeller) in costa rica, $\mathrm{PhD}$ thesis, p. 147, Wageningen University, Wageningen Netherlands, 1974.

[7] E. Opuni-Frimpong, S. M. Opoku, E. Mensah Opoku, and A. J. Storer, "Silvicultural systems for plantation mahogany in Africa: effect of mixed species stands on growth and Hypsipyla attack of African mahogany (Khaya anthotheca and Khaya ivorensis)," Ghana Journal of Forestry, vol. 36, no. 1, pp. 72-88, 2020.

[8] R. H. M. J. Lemmens, "Khaya ivorensis A.chev," in Plant Resources of Tropical Africa 7 (1, D. Louppe, A. A. OtengAmoako, and M. Brink, Eds., Backhuys Publishers, Leiden, Netherlands/CTA, Wageningen, Netherlands, 2008.

[9] A. Maroyi, "Khaya anthotheca (welw.) C.DC," in Plant Resources of Tropical Africa 7 (1, D. Louppe, A. A. OtengAmoako, and M. Brink, Eds., Backhuys Publishers, Leiden, Netherlands/CTA, Wageningen, Netherlands, 2008.

[10] E. Opuni-Frimpong, "Khaya grandifoliola C.DC," in Plant Resources of Tropical Africa 7 (1, D. Louppe, A. A. OtengAmoako, and M. Brink, Eds., Backhuys Publishers, Leiden, Netherlands/CTA, Wageningen, Netherlands, 2008.

[11] K. S. S. Nair, Pest Outbreaks in Tropical Forest Plantations. Is There a Greater Risk for Exotic Tree Species?, Center for International Forestry Research (CIFOR), Bogor, Indonesia, 2001.

[12] E. Opuni-Frimpong, D. F. Karnosky, A. J. Storer, and J. R. Cobbinah, "Silvicultural systems for plantation mahogany in Africa: influences of canopy shade on tree growth and pest damage," For. Ecol. Manage.vol. 255, pp. 328-333, 2008.

[13] F. M. Santos, G. Terra, G. M. Chaer, and M. A. Monte, "Modeling the height-diameter relationship and volume of young African mahoganies established in successional agroforestry systems in northeastern Brazil," New Forests, vol. 50, pp. 389-407, 2019.

[14] C. Hauxwell, J. Mayhew, and A. Newton, "Silvicultural management of Hypsipyla species," in Proceedings of the an International Workshop on Hypsipyla Shoot Borers of the Meliaceae, Kandy, Srilanka, 1996, F. Floyd and C. Hauxwell, Eds., pp. 151-163pp. 151-, Canberra, Australia, September 2001.

[15] E. M. Opoku, E. Opuni-Frimpong, and D. Dompreh, "Developing sustainable regeneration techniques for four African mahogany species: grafting methods for success and growth," New Forests, vol. 50, no. 46, p. 1, 2018.

[16] E. Opuni-Frimpong, S. M. Opoku, A. J. Storer, A. J. Burton, and D. Yeboah, "Productivity, pest tolerance and carbon sequestration of Khaya grandifoliola in the dry semi-deciduous forest of Ghana: a comparison in pure stands and mixed stands," New Forests, vol. 44, no. 6, pp. 863-879, 2013.

[17] A. Altamirano, G. Valladares, N. Kuzmanich, and A. Salvo, "Galling insects in a fragmented forest: incidence of habitat loss, edge effects and plant availability," Journal of Insect Conservation, vol. 20, no. 1, pp. 119-127, 2016.

[18] C. B. Darko, "The influence of mixed planting on the growth, performance and Hypsipyla robusta attacks on Khaya grandifoliola saplings," BSc. thesis, p. 38, Kwame Nkrumah University of Science and Technology, Kumasi, Ghana, 2010.

[19] J. Abraham, S. Angeli, S. Schuetz, B. Weissbecker, and E. Opuni-Frimpong, "Olfactory cues of female Hypsipyla robusta (Moore) (Lepidoptera: Pyralidae) to mahoganies of the genera, Entandrophragma and Khaya," International Forestry Review, vol. 12, no. 5, p. 111, 2010.

[20] J. Mo, M. T. Tanton, and F. L. Bygrave, "Temporal and intertree variations of attack by Hypsipyla robusta moore (Lepidoptera: Pyralidae) in Australian Red Cedar (Toona australis (F. Muell.) Harmes)," For. Ecol. and Manage, vol. 96, pp. 139-146, 1997.

[21] S. A. Cunningham and R. B. Floyd, "Leaf compositional differences predict variation in Hypsipyla robusta damage to Toona ciliata in field trials," Canadian Journal of Forest Research, vol. 34, no. 3, pp. 642-648, 2004.

[22] R. M. Mahroof, C. Hauxwell, J. P. Edirisinghe, and A. D. Watt, "Effects of artificial shade on attack by the mahogany shoot borer, Hypsipyla robusta (Moore)," Agricultural and Forest Entomology, vol. 4, pp. 283-292, 2002.

[23] J. B. Hall and M. D. Swain, Distribution and Ecology of Vascula Plants in a Tropical Rain Forest, Forest Vegetation in Ghana, p. 383, Dr. W. Junk Publisher, London, UK, 1981.

[24] P. Chaikaew, O. Adeyemi, A. O. Hamilton, and O. Clifford, "Spatial characteristics and economic value of threatened species (Khaya ivorensis)," Scientific Reports, vol. 10, no. 1, p. $6266,2020$.

[25] J. P. Cornelius, "The effectiveness of pruning in mitigating Hypsipyla grandella attack on young mahogany (Swietenia macrophylla King) trees," Forest Ecology and Management, vol. 148, no. 1-3, pp. 287-289, 2001.

[26] D. A. Ofori, E. Opuni-Frimpong, and J. R. Cobbinah, "Provenance variation in Khaya species for growth and resistance to shoot borer Hypsipyla robusta," For. Ecol. and Manage.vol. 242, pp. 438-443, 2007.

[27] A. C. Newton, A. D. Watt, F. Lopez, J. P. Cornelius, J. F. Mesén, and E. A. Corea, "Genetic variations in host susceptibility to attack by the mahogany shoot borer, Hypsipyla grandella (Zeller)," Agricultural and Forest Entomology, vol. 1, pp. 11-18, 1999.

[28] Statistixl Post Hoc tests (trial version). http://www.statistixl. com. (accessed on 2014 November 2).

[29] Graphpad Prism (Trial Version 5). http://www.graphpad.com (accessed 2015 September 12).

[30] P. W. Price, "The plant vigour hypothesis and herbivore attack," Oikos, vol. 62, pp. 244-251, 1991.

[31] S. A. Cunningham and R. B. Floyd, "Toona ciliata that suffer frequent height-reducing herbivore damage by a shoot-boring moth (Hypsipyla robusta) are taller," Forest Ecology and Management, vol. 225, no. 1-3, pp. 400-403, 2006.

[32] J. E. Mayhew and A. C. Newton, The Silviculture of Mahogany, p. 226, CABI Publishing, CABI International, Wallingford, UK, 1998.

[33] P. Grijpma, "Resistance of Meliaceae against the shoot borer Hypsipyla with particular reference to Toona ciliata M. J. Roem. var Australia (F.v. Muell.) C.D.C," in Tropical Trees: Variation, Breeding, and Conservation, J. Burley and B. T. Styles, Eds., pp. 69-78, Academic Press, London, UK, 1976.

[34] A. Heisswolf, E. Obermaier, and H. J. Poethke, "Selection of large host plants for oviposition by a monophagous leaf beetle: nutritional quality or enemy-free space?" Ecological Entomology, vol. 30, no. 3, pp. 299-306, 2005.

[35] M. L. Faria, C. E. V. Grelle, C. V. M. Filho, and G. W. Fernandes, "Module selection by A scarabaeidae beetle on erythroxylum suberosum in serra do cipó, minas gerais. Brazil. Ecotropicos," Sociedad Venezolana de Ecología, vol. 10, no. 1, pp. 29-32, 1997. 
[36] R. Taveras, L. Hilje, P. Hanson, R. Mexzón, M. Carballo, and C. Navarro, "Population trends and damage patterns of Hypsipyla grandella (Lepidoptera: Pyralidae) in a mahogany stand, in Turrialba, Costa Rica," Agricultural and Forest Entomology, vol. 6, pp. 89-98, 2004.

[37] L. Cipião, R. R. Bandeira, and S. M. Sílvia Maússe Sitoe, "Incidence of Hypsipyla sp. (Lepidoptera: Pyralidae) and its population distribution on Khaya anthotheca (Meliaceae) stands in the manica province, central Mozambique," in Proceedings of the XIII World Forestry Congress, pp. 1-7, Buenos Aires, Argentina, October 2009.

[38] W. Sakchoowong, C. Chobtham, and S. Rattanachan, "Effects of tree shade on attacks by the red cedar shoot borer, Hypsipyla robusta (moore) (Lepidoptera: Pyralidae) ka-setsart," J. (Nat. Sci.), vol. 42, pp. 435-443, 2008.

[39] J. P. Cornelius and A. D. Watt, "Genetic variation in a Hypsipyla-attacked clonal trial of Cedrela odorata under two pruning regimes," Forest Ecology and Management, vol. 183, no. 1-3, pp. 341-349, 2003. 